4

\title{
Potential nitrogen fixation changes under different land uses as influenced by seasons and biochar amendments
}

\author{
Agota Horel $^{1} \cdot$ Imre Potyo $^{1} \cdot$ Tibor Szili-Kovacs $^{1} \cdot$ Sandor Molnar $^{1}$ \\ Received: 15 June 2018 / Accepted: 10 September 2018 \\ (C) Saudi Society for Geosciences 2018
}

\begin{abstract}
Soil nutrient dynamics, potential biological nitrogen fixation (BNF) changes, and their relations were studied using four land use types. Further, we investigated BNF changes in the presence of biochar in soils. Soil samples were collected from arable, vineyard, grassland, and forest soils during four seasons, and analyzed for abiotic contents of total nitrogen, $\mathrm{NH}_{4}{ }^{+}-\mathrm{N}, \mathrm{NO}_{3}{ }^{-}-$ $\mathrm{N}$, ammonium lactate (AL)-soluble $\mathrm{K}_{2} \mathrm{O}, \mathrm{P}_{2} \mathrm{O}_{5}$, and soil organic carbon (SOC) concentrations. Potential $\mathrm{N}_{2}$ fixation was measured as ethylene $\left(\mathrm{C}_{2} \mathrm{H}_{4}\right)$ production from acetylene $\left(\mathrm{C}_{2} \mathrm{H}_{2}\right)$ reduction $(A R A)$. The study focused on the changes in ARA when different types of biochars (T600, T650, and T700) were applied to soil samples in different amounts $(0,0.5,2.5$, and 5.0\% $\mathrm{wt} \mathrm{wt}^{-1}$ ) under laboratory conditions. We found strong correlations between soil chemical parameters and ARA values, especially in the case of soil $\mathrm{pH}$, total $\mathrm{N}$, SOC, and $\mathrm{P}_{2} \mathrm{O}_{5}$ contents. In the case of arable soil, the ARA measurements were up to 227 times higher compared to grassland and forest samples. Biochar application affected $\mathrm{N}_{2}$-fixing microbial responses among land use types, most notably decreases in arable lands and forest soils. We found that a high amount of biochar added to the soils can greatly suppress $\mathrm{N}_{2}$-fixing activities. Our results highlight the strong relationship between soil nutrient changes and the intensity of anthropogenic influence.
\end{abstract}

Keywords Arable $\cdot$ BNF $\cdot$ ARA $\cdot$ Forest $\cdot$ Grassland · Vineyard

\section{Introduction}

Anthropogenic activities affect soil nutrient dynamics including nitrogen cycling in agroecosystems. Long-term cultivation and management of a given land use may result in significant alterations in soil nutrient cycles and microbial community compositions Ye et al. 2009). Different tillage practices or addition of fertilizers to soils can further modify soil structures and microbial communities that consequently influence soil biochemical processes (Mijangos et al. 2006). Land use and plant types in a given area can determine the requirement for additional nutrients that need to be added to the soil for better crop growth and yield (Fageria 2001). Loss of plant nutrients

This article is part of the Topical Collection on Implications of Biochar Application to Soil Environment under Arid Conditions

Agota Horel

horel.agota@agrar.mta.hu

1 Institute of Soil Sciences and Agricultural Chemistry, Centre for Agricultural Research, Hungarian Academy of Sciences, Herman O. St. 15, Budapest 1022, Hungary can occur in different ways when applied in excess. Nitrogen mostly leaves the soil matrix through hydrological and biogeochemical processes, e.g., leaching, ammonia volatilization, or by gaseous loss through nitrification and denitrification (Reddy et al. 1984). In agricultural croplands, such as winter wheat or grapes, fertilizer application and soil tillage are common practices to ensure high crop yield or better water infiltration (Kanwar et al. 1988), while in the case of grassland and forest soils, the anthropogenic impact is less disruptive. Therefore, for a better understanding of the complexity of land use systems on soil nutrient dynamics in a given area, different land uses should be investigated.

The fixation of $\mathrm{N}_{2}$ is a very important path to enhance the soil nitrogen availability in many ecosystems. When nitrogen is present in soils in limited supply, the rates of BNF can increase. $\mathrm{N}_{2}$-fixing bacteria, called diazotrophs, can convert $\mathrm{N}_{2}$ gas to ammonia using nitrogenase enzymes, which provide available nitrogen for plants (Santi et al. 2013). $\mathrm{N}_{2}$-fixing bacteria are responsible for approximately $90 \times 10^{12} \mathrm{~g}$ biologically fixed nitrogen per year in the case of agricultural land, and an additional $50 \times 10^{12} \mathrm{~g}$ biological nitrogen fix per year for forest and non-agricultural lands, globally (Bezdicek and 
Kennedy 1998). $\mathrm{N}_{2}$ fixation is altered by human activities (Vitousek et al. 1997) as fertilizer application to cultivated soils can greatly influence the microbial density and diversity of the soil (Maharning et al. 2009). Several types of free-living $\mathrm{N}_{2}$-fixing bacteria are present in soils, either anaerobes such as Desulfovibrio and Clostridium spp., or aerobe phototrophs, e.g. Cyanobacteria, or aerobe heterotroph Azotobacter spp.

In recent years, soil additives such as biochar are getting extra attention as they might help crop production in agricultural fields and also can mitigate negative effects of greenhouse gases originating from the soils. Recent studies on the effect of biochar application to soils and its rates to fix $\mathrm{N}_{2}$ vary in literature. While there are several studies investigating symbiotic biological $\mathrm{N}_{2}$ fixation (BNF) response to biochar amendment to soils (Rillig et al. 2010; Rondon et al. 2007), non-symbiotic or free-living $\mathrm{N}_{2}$-fixing bacterial communities' responses are less studied (Atkinson et al. 2010). It has been reported that biochar can increase BNF in agricultural soils such as soils planted with red clover (Mia et al. 2014) or common beans (Rondon et al. 2007). Biochar can also increase the alkalinity of acidic soils, creating more favorable conditions for $\mathrm{N}_{2}$-fixing bacteria (Rondon et al. 2007), though a decrease in BNF rates at high biochar amendments might also occur. Our current knowledge on the direct and indirect effects of biochar application to soils on various nitrogen cycling processes, such as $\mathrm{N}_{2}$ fixation or nitrogen mineralization, is still lacking (DeLuca et al. 2009); therefore, soil and biochar-specific studies should be conducted prior to soil additive use, especially in the case of soils sowed with nonlegume plants.

In this paper, we aimed at assessing nutrient and ARA changes in four land use types (arable, vineyard, forest, and grassland) during different seasons, where the land uses have similar soil structures. Since the intensity of anthropogenic influence on nitrogen cycling processes is still less known with new soil additives being developed to promote agricultural productivities, we investigated how different types and amount of biochar addition influence the ARA rates of these land uses. We hypothesized that (i) soil nutrient and ARA changes will differ considerably among land use types and seasons, (ii) disruptions in soil chemical parameters can negatively affect potential BNF rates, and (iii) different amounts and types of biochar amendments to soils influence the rates of ARA differently.

\section{Materials and methods}

To address our hypotheses on how anthropogenic activities alter soil biotic and abiotic processes, we performed our experiments in two ways. The present study included field trials investigating soil chemical changes with special emphasis on nitrogen fixation potentials over time under different land uses. Later, we supplemented our findings with data retrieved from a laboratory experiment where we could closely monitor microbial response to biochar amendments focusing on changes in ARA, using soil samples collected from the field.

\section{Soil sampling, site information, and soil chemical analyses}

Soil samples (Luvisol, WRB) were collected from (i) a tilled arable soil sowed with winter wheat $\left(46.92649^{\circ} \mathrm{N}, 17.68246^{\circ}\right.$ E), (ii) a vineyard (Vitis vinifera; $46.9166^{\circ} \mathrm{N}, 17.68976^{\circ} \mathrm{E}$ ), (iii) a grassland (meadow; $46.91232^{\circ} \mathrm{N}, 17.69754^{\circ} \mathrm{E}$ ), and (iv) a forested area (oak and maple mix; $46.91283^{\circ} \mathrm{N}$, $17.69723^{\circ} \mathrm{E}$ ). All soil samples were collected from a small agricultural catchment located in Balaton Uplands, Hungary. The four land use types were chosen as they represent different time scales and levels of human impacts on soils and also characterize large portions of many agricultural lands at a given area. Arable land experiences annual plowing and frequent fertilizer and herbicide applications, and crop rotation (e.g., winter wheat, triticale). Vineyards have the same plant every year receiving in-row plowing, with frequent fertilizer applications. Grasslands have only hay harvesting, but no tillage or chemical amendments. Soil from the forest floor receives minimal anthropogenic impact, as no tree cutting was performed nor were any dead trees removed in recent decades.

All samples were taken from the upper $2-12 \mathrm{~cm}$ soil layer by sample corer at three sampling points per land use evenly distributed along an approximately 15 -m-long transect line. Samples were collected 3 months apart in February, May, July, and November, representing all four seasons, respectively. All soil samples in vineyards were collected from in-row plowing area. Soil samples were homogenized and analyzed for total nitrogen content, $\mathrm{NH}_{4}{ }^{+}-\mathrm{N}, \mathrm{NO}_{3}{ }^{-}-\mathrm{N}, \mathrm{K}_{2} \mathrm{O}$ (AL soluble), $\mathrm{P}_{2} \mathrm{O}_{5}$ (AL soluble), soil organic carbon ( $\mathrm{SOC}$ ), electrical conductivity, and $\mathrm{pH}_{\mathrm{H} 2 \mathrm{O}} \cdot \mathrm{NH}_{4}{ }^{+} \mathrm{N}$ and $\mathrm{NO}_{3}{ }^{-} \mathrm{N}$ values were obtained based on $\mathrm{KCl}$ extraction and stream distillation technique. SOC contents were measured by wet digestion using the Tyurin method. The total nitrogen was determined using the modified Kjeldahl method (ISO 11261:1995). $\mathrm{K}_{2} \mathrm{O}$ and $\mathrm{P}_{2} \mathrm{O}_{5}$ measurements were done using an inductively coupled plasma optical emission spectrometry (Quotation ICP-OES, Ultima 2) after ammonium lactate extraction (AL). Most of these measurements in the present study were chosen as basic indicators to analyze soil chemical changes and nutrient dynamics, so we could get a more complete picture of carbon and nitrogen cycling at the investigated sites. In addition, we also measured $\mathrm{CaCO}_{3}$ contents using Scheibler calcimeter for the arable and vineyard soils. Soil element concentrations are reported as $\mathrm{m} \mathrm{kg}^{-1}$ dry weight soil.

Particle size distribution was determined using the sievepipette method, where arable, vineyard, grass, and forest soil had $10.4 \pm 0.84,12.05 \pm 1.32,22.67 \pm 0.81$, and $15.86 \pm$ 
$1610.31 \%$ sand content $(2-0.05 \mathrm{~mm}), 44.8 \pm 1.14,36.18 \pm 2.70$,

$16239.85 \pm 2.78$, and $54.95 \pm 0.53 \%$ silt $(0.05-0.002 \mathrm{~mm})$, and $16344.78 \pm 0.31,51.76 \pm 2.70,37.48 \pm 2.26$, and $29.19 \pm 0.30 \%$

164 clay $(<0.002 \mathrm{~mm})$ content, respectively.

\section{Biochar types used in the experiment}

The chemical characteristics of the three types of biochar prepared at three pyrolysis temperatures (T600, T650, and T700) used in the present study are shown in Table 1 . The three biochar types were manufactured at factories provided with European Biochar Certificates. According to the manufacturers' information, biochar T600 was made from cellulose fibers and grain husks using Pyreg technology at $600{ }^{\circ} \mathrm{C}$; biochar T650 was made from woodchips with Pyreg technology at approximately $650{ }^{\circ} \mathrm{C}$; and biochar T700 was made from woodchips using the Schottdorf system at approximately $700{ }^{\circ} \mathrm{C}$. The biochars were analyzed for different nutrient concentrations such as $\mathrm{NH}_{4}{ }^{+}-$ $\mathrm{N}, \mathrm{NO}_{3}{ }^{-}-\mathrm{N}$, total nitrogen content, $\mathrm{P}_{2} \mathrm{O}_{5}, \mathrm{~K}_{2} \mathrm{O}$, and $\mathrm{pH}$ using the same standard chemical techniques described for soil samples.

\section{Measuring potential $\mathbf{N}_{\mathbf{2}}$-fixing bacterial activities using gas chromatography with flame ionization detector}

Soil samples for all four land use types were analyzed for potential BNF rates calculated from acetylene reduction. The effects of different biochar types and amounts were also investigated on samples collected during spring (May). Potential nitrogen $\left(\mathrm{N}_{2}\right)$ fixation or $\mathrm{BNF}$ was measured as ethylene $\left(\mathrm{C}_{2} \mathrm{H}_{4}\right)$ production from acetylene $\left(\mathrm{C}_{2} \mathrm{H}_{2}\right)$ reduction (ARA) (Welsh et al. 1996). From the homogenized soil, $10 \mathrm{~g}$ dry weight soil was added to triplicate $27-\mathrm{ml}$ serum vials. The different biochar amounts $(0,0.5 \%, 2.5 \%$, and $5.0 \%$ ) of $\mathrm{T} 600$, T650, and T700 were added to the vials prior to the addition of $4 \mathrm{ml}$ of glucose solution $\left(50 \mathrm{~g} \mathrm{l}^{-1}\right)$ in distilled water. Control samples had no biochar addition. Vials then were capped and placed in an incubator for $24 \mathrm{~h}$ at $25^{\circ} \mathrm{C}$ to increase the number of heterotrophic nitrogenfixing bacteria in the soil. All samples but controls received $10 \%(v / v)$ of $\mathrm{C}_{2} \mathrm{H}_{2}$, added to the headspace of the vials, and incubated for an additional hour. Samples without $\mathrm{C}_{2} \mathrm{H}_{2}$ were used to develop a baseline for occasional ethylene production in the soil samples, with the values deducted from the measured concentrations. After $1 \mathrm{~h}$ incubation, the samples were measured for ethylene production. Production of $\mathrm{C}_{2} \mathrm{H}_{4}$ from the reduction of $\mathrm{C}_{2} \mathrm{H}_{2}$ as a substrate analog of $\mathrm{N}_{2}$ was measured using a FISONS 8000 gas chromatograph with flame ionization detector (GC-FID). All rates and fluxes pertaining to nitrogen species are expressed on a nitrogen atom basis.

The GC-FID oven temperature was held constant at $80{ }^{\circ} \mathrm{C}$, while the detector temperature was held at $100{ }^{\circ} \mathrm{C}$ during measurements. The carrier gas was nitrogen with a constant flow of $30 \mathrm{ml} \mathrm{min}^{-1}(170 \mathrm{kPa})$. The GC column Porapak N (80-100 mesh) was 2-3 m in length with $2.1 \mathrm{~mm}$ internal diameter and $3.2 \mathrm{~mm}$ outer diameter. Gas samples $(125 \mu \mathrm{l})$ were manually injected into the GC. Ethylene standards (10 $\mathrm{mg} \mathrm{kg}^{-1}$ ) were used to quantify measurements and to qualify instrument reliability after being in use for a longer period of time. Ethylene concentration was calculated from the peak area provided by the Clarity software using calibration gas.

\section{Statistics}

The factors of land use types (arable, vineyard, grassland, or forest), biochar types, and amounts (T600, T650, or T700; 0, $0.5,2.5$, or $5.0 \%$ by weight), as well as their interactions in relation to non-amended soils ( 0 or control), were analyzed using one- or two-way analysis of variance (ANOVA) followed by a post hoc Tukey HSD test. Residuals were checked for normal distribution and data were transformed (Box-Cox transformation) where necessary. All statistical calculations were performed using the software package $\mathrm{R}$ (Version 2.15.2). Statistical significance of the data sets was determined at $p<0.05$ and $p<0.01$.

Q1 t1.1 Table 1 Chemical characteristics of the three biochar types used in the experiment $(n=3 ; \pm \mathrm{SD})$

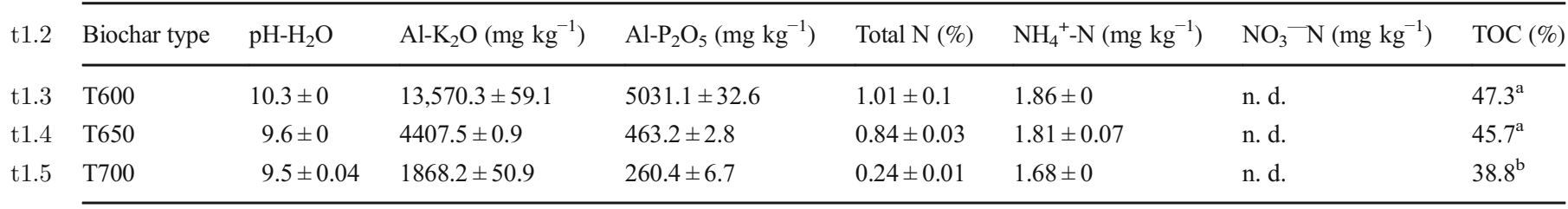

$\mathrm{T} 600, \mathrm{~T} 650$, and $\mathrm{T} 700$ represent biochar pyrolysis temperatures of 600,650 , and $700{ }^{\circ} \mathrm{C}$

TOC total organic carbon values, $n$. $d$. not detectable

a Data were based on manufacturers' certificate

${ }^{\mathrm{b}}$ Soil organic carbon (SOC; \%) 


\section{Results}

t2.11 August

t2.12 Summer

t2.13

$\mathrm{t} 2.14$

t2.15 November

t2.16 Fall

$\mathrm{t} 2.17$

$\mathrm{t} 2.18$

February

Winter

May

Spring

Fall

Soil samples were collected at four seasonally distinguishable periods to investigate the changes in soil nutrients and BNF rates over time (Table 2, Fig. 1). Analyzing the total nitrogen amount of the four land use types in winter soil samples, arable soil showed significant differences $(p<0.05)$ compared to forest and grassland soils, while vineyard data showed significant differences compared to forest (Table 2). When investigating spring samples, we also observed significant differences between vineyard's and grassland's total $\mathrm{N}$ values. These differences however diminished during summer and fall sampling periods, where none of the land use types' total $\mathrm{N}$ showed statistically significant differences compared to each other (Table 2).

Soil samples collected during winter and spring showed significant differences between arable or vineyard soils' SOC contents compared to grassland or forest soils $(p<0.04)$, while SOC values of the land use types showed no significant differences in summer or fall samples $(p=$ 0.1949 and $p=0.1446$, respectively; Table 2).

Fertilizer addition to agricultural lands is a common practice worldwide to achieve better crop yield; however, it also affects the soils' nitrogen forms. Total $\mathrm{N}$ contents were the highest in samples collected in spring for all land use types except in the case of arable soil, where summer samples had the highest amount. We observed a decrease in total $\mathrm{N}$ concentrations during winter in all land use types. However, total $\mathrm{N}$ data in arable soil only showed significant changes when comparing winter samples to other seasons $(p<0.04)$. In the case of grassland, similar results were observed as in the arable land when analyzing samples collected in spring $(p<0.02)$. In terms of vineyard or forest soils, we did not observe any significant differences in total $\mathrm{N}$ concentrations seasonally.

The trend in changes of SOC over time was similar to changes in total $\mathrm{N}$, all land use soil samples (but arable) showed a peak in its SOC amount during spring and slowly decreased toward the end of the year, while arable soil had similar SOC among seasons with the highest observed in fall months (Table 2). In terms of arable and forest soils, the SOC values did not show significant differences over time $(p>0.05)$. Vineyard SOC values measured in fall soil samples showed significant differences compared to other seasons, while winter, spring, and summer data had no significant differences. In the case of grassland, spring soil samples had significantly greater SOC compared to other seasons' data $(p<0.05)$. Overall, we found significant differences between the four land use types, mainly arable and vineyard compared to grass or forest soils, signifying the connections between human impact and soil nitrogen and carbon stocks.

In general, when analyzing $\mathrm{NH}_{4}{ }^{+}-\mathrm{N}$ and $\mathrm{NO}_{3}{ }^{-}-\mathrm{N}$ data, we did not find any statistically significant differences between land use types in any of the sampling periods (Fig. 1); however, we observed that $\mathrm{NH}_{4}{ }^{+}-\mathrm{N}$ and $\mathrm{NO}_{3}{ }^{-} \mathrm{N}$ concentrations were the highest during the spring and summer months.

Forest soils showed the lowest $\mathrm{K}_{2} \mathrm{O}$ concentrations (124.51-226.67 $\mathrm{mg} \mathrm{kg}^{-1}$ ) with significant differences compared to the other land use types $(p<0.027$; Fig. 2a). Vineyard samples had the highest $\mathrm{K}_{2} \mathrm{O}$ concentrations
263

264

265

266

267

268

269

270

271

272

273

274

275

276

277

278

279

280

281

282

283

284

285

286

287

288

Table 2 Soil chemical characteristics of the four land use types at different sampling periods $(n=3 ; \pm \mathrm{SD})$

Sampling times $\quad$ Land use types $\mathrm{pH}_{(\mathrm{H} 2 \mathrm{O})} \quad$ Total N (\%) $\quad \mathrm{SOC}(\%) \quad \mathrm{CaCO}_{3}(\%) \quad \mathrm{EC}_{\left(\mathrm{mS} \mathrm{cm}^{-1}\right)}$

$\begin{array}{llll}\text { Arable } & 7.98 & \pm 0.02 & 0.21 \\ \text { Vineyard } & 8.01 & \pm 0.02 & 0.23 \\ \text { Grassland } & 6.54 & \pm 0.16 & 0.34 \\ \text { Forest } & 6.11 & \pm 0.37 & 0.43 \\ \text { Arable } & 7.9 & \pm 0.02 & 0.23 \\ \text { Vineyard } & 7.89 & \pm 0.01 & 0.26 \\ \text { Grassland } & 6.85 & \pm 0.15 & 0.49 \\ \text { Forest } & 5.91 & \pm 0.49 & 0.51 \\ \text { Arable } & 7.85 & \pm 0.04 & 0.24 \\ \text { Vineyard } & 7.8 & \pm 0.04 & 0.24 \\ \text { Grassland } & 6.91 & \pm 0.17 & 0.27 \\ \text { Forest } & 5.52 & \pm 0.12 & 0.37 \\ \text { Arable } & 7.78 & \pm 0.05 & 0.24 \\ \text { Vineyard } & 7.87 & \pm 0.02 & 0.21 \\ \text { Grassland } & 6.86 & \pm 0.20 & 0.23 \\ \text { Forest } & 5.38 & \pm 0.14 & 0.3\end{array}$

$\begin{array}{llll} \pm 0.04 & 1.76 & \pm 0.04 & 20.63 \\ \pm 0.02 & 2.07 & \pm 0.11 & 31.92 \\ \pm 0.04 & 3.08 & \pm 0.39 & 0 \\ \pm 0.07 & 3.86 & \pm 0.58 & 0 \\ \pm 0.01 & 1.75 & \pm 0.20 & 20.04 \\ \pm 0.01 & 2.29 & \pm 0.15 & 29.8 \\ \pm 0.06 & 4.24 & \pm 0.48 & 0 \\ \pm 0.05 & 4.62 & \pm 0.20 & 0 \\ \pm 0.01 & 1.6 & \pm 0.14 & 20.35 \\ \pm 0.02 & 2.09 & \pm 0.10 & 31.52 \\ \pm 0.04 & 2.14 & \pm 0.45 & 0 \\ \pm 0.15 & 3.56 & \pm 1.68 & 0 \\ \pm 0.01 & 1.8 & \pm 0.05 & 21.09 \\ \pm 0.02 & 1.68 & \pm 0.19 & 31.46 \\ \pm 0.04 & 2.06 & \pm 0.19 & 0 \\ \pm 0.09 & 2.86 & \pm 0.93 & 0\end{array}$

$\begin{array}{lll} \pm 0.62 & 0.25 & \pm 0.01 \\ \pm 3.54 & 0.29 & \pm 0.02 \\ - & 0.3 & \pm 0.05 \\ - & 0.2 & \pm 0.08 \\ \pm 0.59 & 0.25 & \pm 0.02 \\ \pm 4.89 & 0.33 & \pm 0.01 \\ - & 0.48 & \pm 0.09 \\ - & 0.27 & \pm 0.11 \\ \pm 0.28 & 0.26 & \pm 0.01 \\ \pm 4.48 & 0.37 & \pm 0.02 \\ - & 0.31 & \pm 0.08 \\ - & 0.15 & \pm 0.05 \\ \pm 0.09 & 0.25 & \pm 0.01 \\ \pm 8.20 & 0.27 & \pm 0.01 \\ - & 0.24 & \pm 0.04 \\ - & 0.09 & \pm 0.03\end{array}$




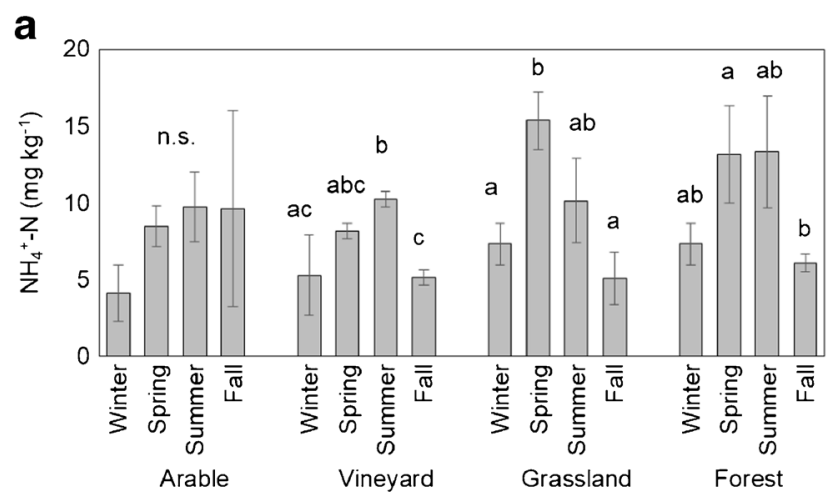

b

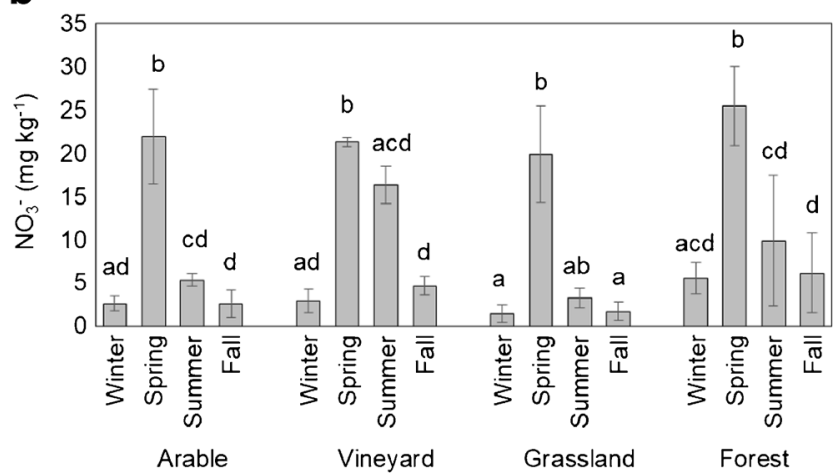

Fig. 1 Soil inorganic nitrogen concentration changes in the various land use types. a $\mathrm{NH}_{4}{ }^{+}-\mathrm{N}$. $\mathbf{b ~ N O}{ }_{3}^{-}{ }^{-} \mathrm{N}$. Nutrient concentrations are on a dry soil mass basis $(n=3 ; \pm \mathrm{SD})$. Statistically significant differences are indicated by different letters within land use types. n.s. not significant

(687.12-997.67 $\mathrm{mg} \mathrm{kg}^{-1}$ ), which also were significantly different compared to the other land uses $(p<0.001)$. In terms of $\mathrm{P}_{2} \mathrm{O}_{5}$ contents, arable land showed the highest values (181.33-233.76 mg kg-1), resulting in substantial differences compared to all other land use $(p<0.004)$, while the lowest (12.24-26.17 $\mathrm{mg} \mathrm{kg}^{-1}$ ) were observed in the case of grass soil (grassland compared to arable $p<0.001$, and vineyard $p=$ 0.005 ; Fig. 2 b), but not in the case of the forest samples. a
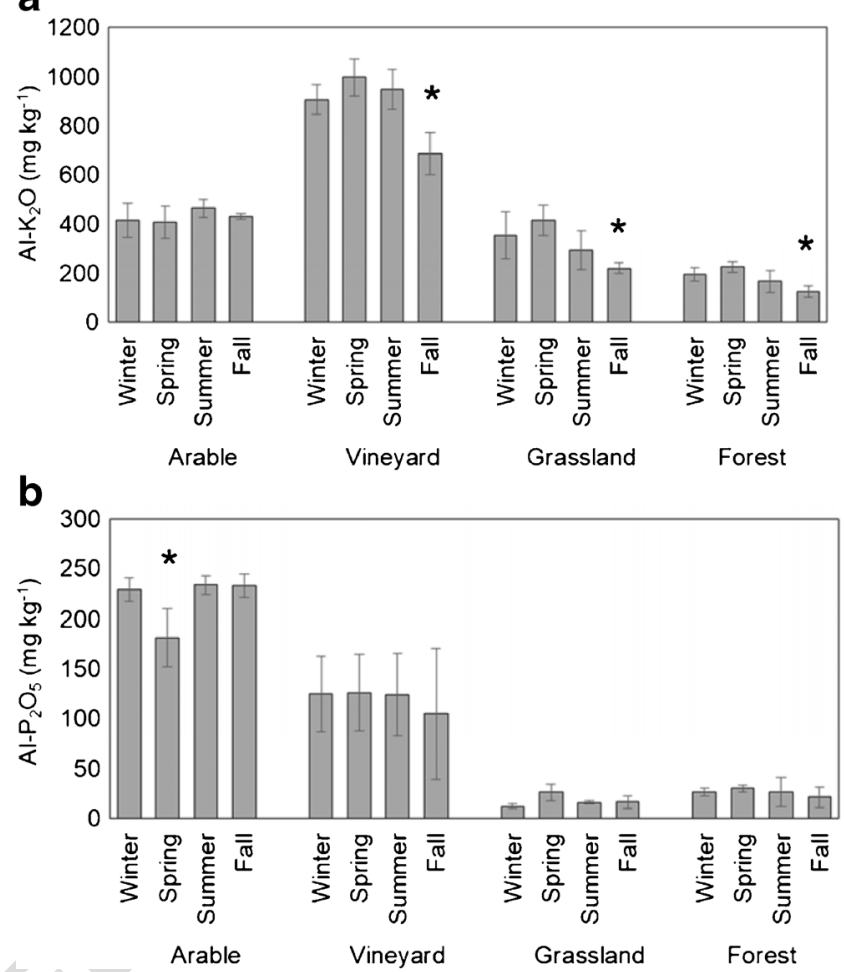

Fig. 2 Soil inorganic nutrient concentration changes in the various land use types. a $\mathrm{K}_{2} \mathrm{O}$. b $\mathrm{P}_{2} \mathrm{O}_{5}$. Nutrient concentrations are on a dry soil mass basis $(n=3 ; \pm \mathrm{SD})$. * represents significance level of $p<0.05$ within land use types

$p<0.014$, and $p<0.008$, respectively) compared to other land use types, while $\mathrm{C}_{2} \mathrm{H}_{2}$ reduction of spring arable soil samples differed significantly only in the case of grassland and forest soils $(p=0.031)$. Seasonal changes did not result in major ARA changes in arable, vineyard, and forest soils. Summer ARA rates in grasslands were significantly different compared to the other seasons ( $p=0.047$; Fig. 3 ).

\section{Relationships between different soil chemical properties and ARA}

As chemical properties of a specific soil can greatly influence its biological reactions, we explored the connections between soil nitrogen, carbon, phosphor, or $\mathrm{pH}$ changes and acetylene reductions (Fig. 4). We found strong correlations between ARA and total $\mathrm{N}$, SOC, soil pH, or $\mathrm{P}_{2} \mathrm{O}_{5}$ contents (Fig. 4). We did not find strong correlations with ARA values when investigating soil $\mathrm{NH}_{4}{ }^{+}-\mathrm{N}$ and $\mathrm{NO}_{3}{ }^{-}-\mathrm{N}$ concentrations $(p=$ 0.26 and $p=0.66$, respectively). Our results showed that with increasing soil total $\mathrm{N}$ or $\mathrm{SOC}$ concentrations, the $\mathrm{N}_{2}$ fixation potential decreased. In the case of $\mathrm{P}_{2} \mathrm{O}_{5}$ data, we found that at low concentrations, the acetylene reductions were low as well, and increasing $\mathrm{P}_{2} \mathrm{O}_{5}$ contents resulted in increased ARA values. In the case of soil $\mathrm{pH}$, we observed that acidic conditions resulted in low ARA, while around $\mathrm{pH} 8$, the ARA were 


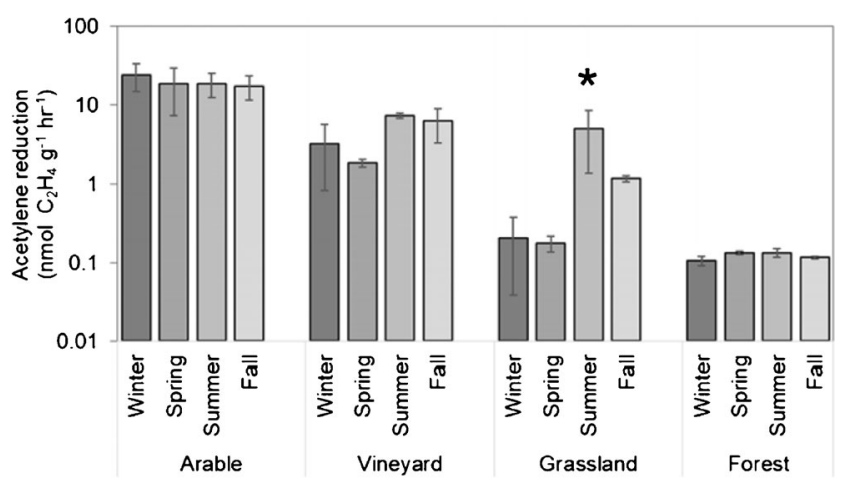

Fig. 3 Acetylene reduction activity (ARA) of soil samples of the varying land use types collected during different seasons, based on $\mathrm{C}_{2} \mathrm{H}_{4}$ production rate. $*$ represents significance level of $p<0.05$ within land use types; $n=3, \pm \mathrm{SD}$

no longer inhibited and the values were influenced by other soil parameters (Fig. 4d). land with up to $18.42 \pm 11.1 \mathrm{nmol} \mathrm{C}_{2} \mathrm{H}_{4} \mathrm{~g}^{-1} \mathrm{~h}^{-1}$ followed by vineyard soils, where soil amendment frequently includes the use of fertilizer (Fig. 5a, b). In the case of grassland and forest soils, the ARA values were considerably lower compared to arable or vineyard soils, ranging between 0.15 and $0.25 \mathrm{nmol}$ $\mathrm{C}_{2} \mathrm{H}_{4} \mathrm{~g}^{-1} \mathrm{~h}^{-1}$ (forest $5.0 \% \mathrm{~T} 700$ and grassland $0.5 \% \mathrm{~T} 700$, respectively; Fig. 5c, d).

When examining the type of biochars used in the experiment, we found that T600 addition to soils provided higher BNF rates in most cases compared to the other two types of biochars (Fig. 5). Ethylene production from soils amended with T650 or T700 biochars showed very similar microbial responses (Fig. 5), showing that different biochars can extensively influence microbial activities. Comparing to control, we also found significant difference in ARA for the arable soil compared to the T650- or T700amended soils $(p<0.001)$, except for $0.5 \%$ T650 vineyard $(p=0.0511)$ and $5.0 \%$ T700 vineyard soils $(p=0.0594)$. T600-amended samples showed a slight increase in $\mathrm{N}_{2}$ fixation rates in arable soils compared to control treatments; however, significant differences were mainly observed in the $0.5 \%$ T600-amended arable soils compared to the other treatments. Although these differences were significant, it is also worth noting that all $p$ values were above 0.0485 .

When investigating samples with the lowest amount of biochar application $(0.5 \%)$ among the different types of biochars, we only observed significant differences between
349

350

351

352

353

354

355

356

357

358

359

360

361

362

363

364

365

366

367

368

369

370

371 a

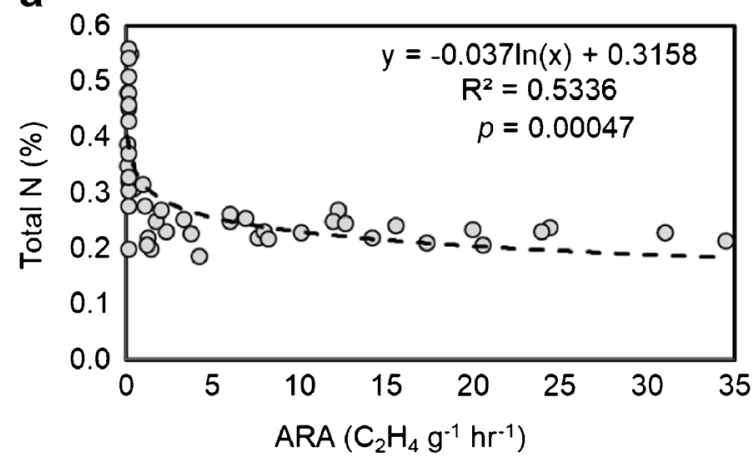

C

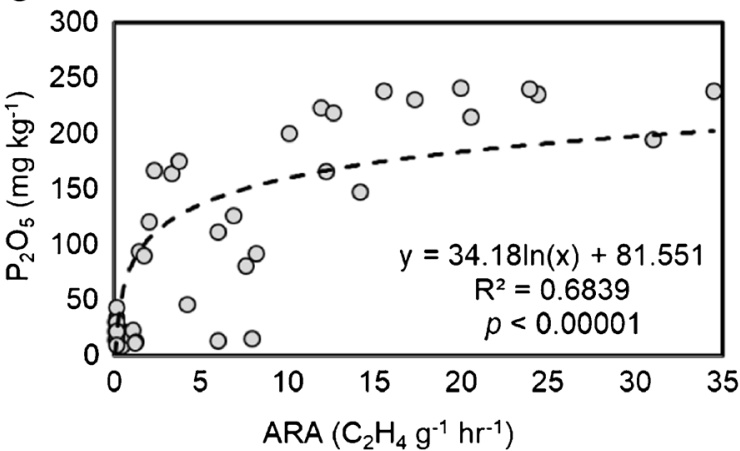

b

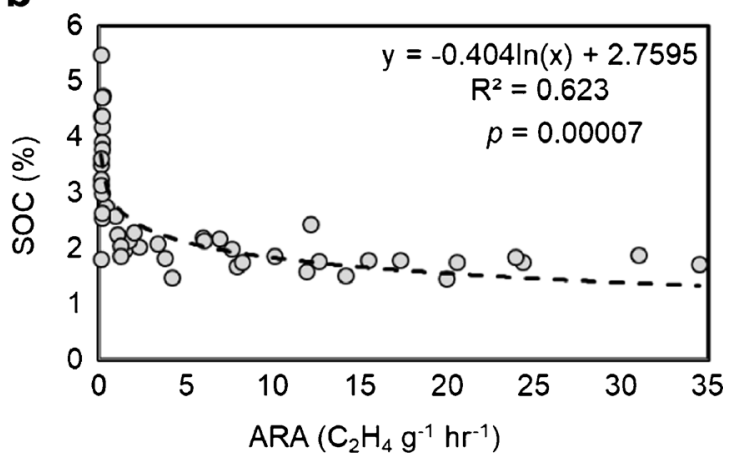

d

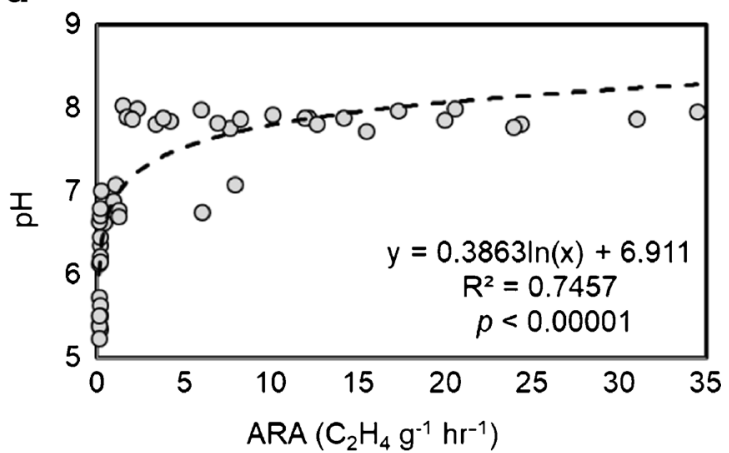

Fig. 4 Relationships between soil chemical properties of a total $\mathrm{N}$, b SOC, $\mathbf{c} \mathrm{P}_{2} \mathrm{O}_{5}, \mathbf{d}$ pH, and acetylene reduction activity (ARA) measured for the different land uses. $n=48$ 
T600-amended arable soil, mostly grassland, and forest soils $(p<0.02$; Fig. 5 ), while all other low biochar amounts did not result in significant differences in ARA values. When $2.5 \%$ biochar was added to the soil samples, all ARA reduced to a level, where substantial changes within land use types and biochar types $(p=0.057)$ could not be observed. The 5.0\% biochar addition resulted in a major decrease in ARA for all soils regardless of land use types $(p=0.028)$.

\section{Discussion}

In the present study, potential BNF rates, as analog to acetylene reduction activities, showed a substantial increase in its values during summer and fall compared to winter or spring. This increase was the most noticeable in the grassland soil samples. The increase in BNF rates could be related to elevated temperatures during summer and fall seasons, as one of the major differences between sampling sites was the seasonal temperature shift. Although biological $\mathrm{N}_{2}$ fixing has shown significant changes with varying temperature and soil moisture (Belnap 2003; Horel et al. 2014), in the present study, the other sampling sites' BNF rates were less pronounced when considering temperature differences only. Our finding suggests the diversity of microbial communities and/or densities among sites rather than climatic factors. Many agricultural sites during hot summer with low soil moisture and cold winter temperatures can result in suppressed nitrogenase and metabolic activities of the microbial communities, leading to low $\mathrm{N}_{2}$ fixation values (Belnap 2003). In the present study, winter temperatures were unusually high for the area with below average precipitation amount. However, during summer and fall months, several rain events took place, which could cause the increase in microbial density, hence resulting in higher BNF potentials. Soil moisture differences can influence microbial responses to available carbon source at a given area, which further can be influenced by different vegetation succession stages (Surda et al. 2015). Leaf interception, especially in the case of forest, can significantly reduce the throughfall amount, which in summer months can result in significantly lowered soil moisture contents. In the present study, summer soil moisture contents of forest soil were $55.9 \%$ less than when compared to spring samples; however, the $\mathrm{N}_{2}$ fixation potentials were not affected by these differences among seasons.

Chemical characteristics of the investigated soil can further influence BNF rates. $\mathrm{pH}$ ranges of soils can affect $\mathrm{N}_{2}$-fixing rates, as very acidic conditions can inhibit nitrogenase activities (Limmer and Drake 1996), while at close to neutral values, the $\mathrm{N}_{2}$ fixation is known to be optimal (Roper and Smith 1991). This statement is further supported by our findings. Forest and grassland soils had $\mathrm{pH}$ below 7 , and vineyard and arable around $\mathrm{pH} 7.9$, explaining some of the observed
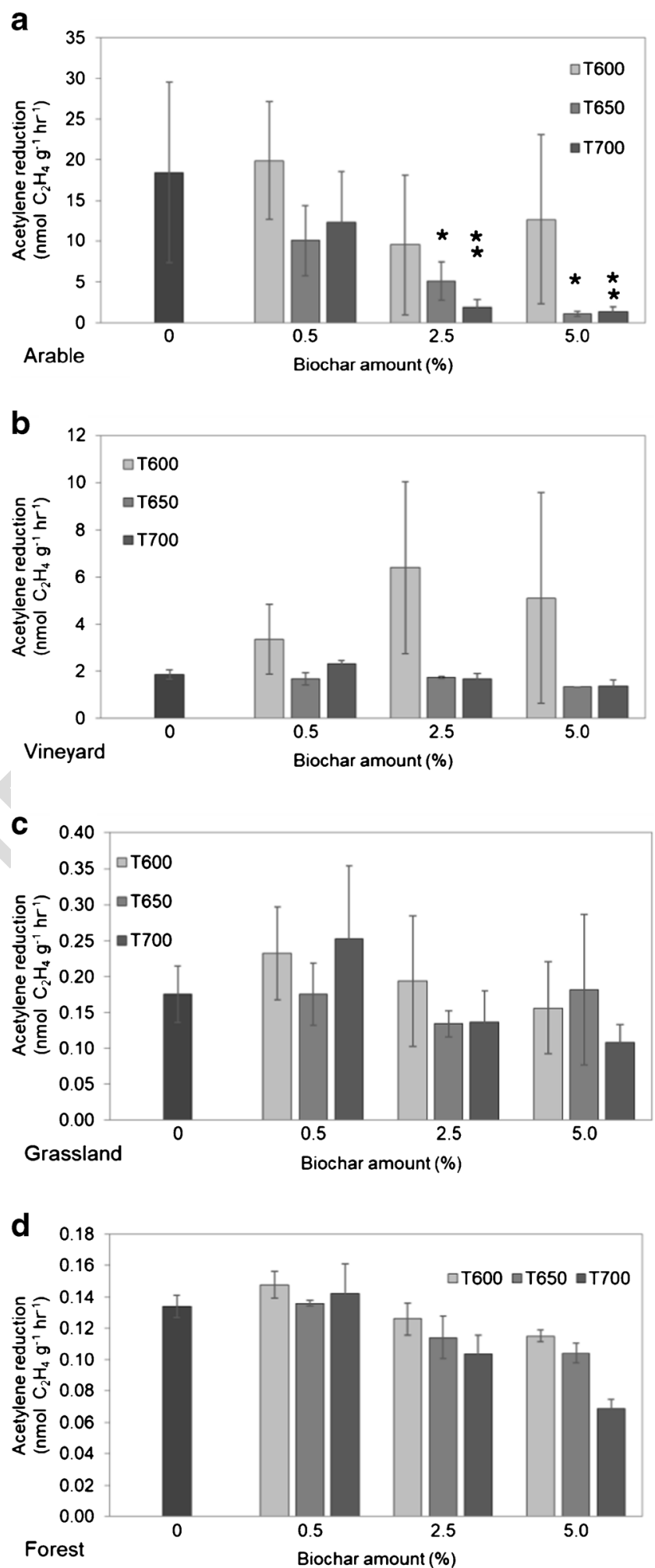

Fig. 5 Effects of the different biochar applications on acetylene reduction activity (ARA) values of $\mathbf{a}$ arable, $\mathbf{b}$ vineyard, $\mathbf{c}$ grassland, and $\mathbf{d}$ forest soils, based on $\mathrm{C}_{2} \mathrm{H}_{4}$ production rate. * and ** represent within land use type significance level of $p<0.05$ and $p<0.01$, respectively; $n=3, \pm \mathrm{SD}$

ARA differences between land use types. Fertilizer addition to $\quad 426$ soils also has a major role in soil microbial activities. Cusack 
et al. (2009) found that fertilizer application can negatively influence BNF rates in tropical forest soils. Even though in the present study forest soils did not receive any fertilizer treatments, our investigated forest soils also showed some minor increases in ARA during spring and summer. Soil nutrient levels can also influence BNF rates. Mineral nitrogen can inhibit BNF, due to diversion of photosynthates to assimilate nitrates (Mulongoy 1995). The amount of nitrate present in soil can affect $\mathrm{N}_{2}$ fixation. While a low amount of nitrate delays $\mathrm{N}_{2} \mathrm{O}$ reduction to $\mathrm{N}_{2}$ via $\mathrm{BNF}$, a high amount of nitrates can suppress or even inhibit BNF process (Blackmer and Bremner 1978). In the present study, significant difference in $\mathrm{NO}_{3}{ }^{-}$measurements between seasons was observed only in the case of spring samples, while between land uses, the concentrations were relatively similar (Fig. 1b). When we investigated nitrate concentration and the BNF rates between seasons or land uses, no connections could be observed. Therefore, in our study, the amount of nitrate present in the soil was not a major controlling factor in BNF changes. Phosphorous deficiency in soil can decrease $\mathrm{N}_{2}$ fixation along with causing reduction in nodulation and plant growth (Mulongoy 1995). Our findings further support this statement. Soil $\mathrm{P}_{2} \mathrm{O}_{5}$ concentrations below $50 \mathrm{mg} \mathrm{kg}^{-1}$ inhibited, while above $150 \mathrm{mg} \mathrm{kg}^{-1}$ enabled $\mathrm{N}_{2}$ fixation (Fig. 4c).

Soil amendments such as activated carbon or biochar can also influence the availability of certain nutrients and soil moisture for plants and bacteria to use (Schiewer and Horel 2017; Thies and Rillig 2009). Biochars are generally lacking in inorganic nitrogen, which can enhance diazotrophs for colonization on the biochars' large surface area (Atkinson et al. 2010), consequently affecting the chemical and physical characteristics of the soil (Gaskin et al. 2010; Horel et al. 2018; Ouyang et al. 2013). With soil amendments, the oxygen levels can shift within the soil matrices, further influencing nitrogenase enzyme activities (Halbleib and Ludden 2000). Uzoma et al. (2011) investigated corn grain nutrient concentration changes as influenced by the different amounts of biochar addition to soils, and found inconsistent data, as total nitrogen decreased with low biochar addition and increased back to similar to control levels with higher biochar amount. Gaskin et al. (2010) observed only marginally increased yield in the case of corn when the effect of different plant-based biochars was investigated, finding additional amendments such as fertilizer to the soil necessary. Similar outcomes were perceived by Steiner et al. (2007), where the application of fertilizer and compost along with biochar resulted in substantial increase in yield, but biochar alone did not. Therefore, alongside biochar, fertilizer addition is also expected in agricultural lands to achieve better crop yield. This can influence soil BNF rates and overall plant growth and health on various scales depending on the type and amount of biochar, and the parameters and locations of the soil matrices receiving the supplements. Quilliam et al.
(2013) investigated clover root nodules and $\mathrm{N}_{2}$ fixation rates after 3 years of biochar application to temperate agricultural soils and found no influence of biochars as nodules had similar numbers and sizes, but the authors found increased nitrogenase activities. BNF rates are very high in legume plants, such as soybeans or peas (Masson-Boivin et al. 2009), and lower in non-symbiotic plant microbial connections with 3 $306 \mathrm{~kg} \mathrm{~N} \mathrm{ha}^{-1} \mathrm{year}^{-1}$ versus approximately $5 \mathrm{~kg} \mathrm{~N} \mathrm{ha}^{-1}$ year $^{-1}$, respectively (Atkinson et al. 2010). In agricultural lands where crop rotation and/or fertilization occurs frequently, the symbiotic $\mathrm{N}_{2}$-fixing plant microbial connections are more likely, helping atmospheric $\mathrm{N}_{2}$-fixing processes further. In the present study, however, increases in ARA due to symbiotic BNF rates were unlikely to occur as no legume plants were present in any of the sampled sites. In our data, the differences in $\mathrm{N}_{2}$-fixing potentials among the four land use types with or without biochar amendment signify the importance of free-living BNF in the nitrogen cycling processes. In our experiment, we used exactly the same amount of soil in all experimental setup while varying the biochar amounts; consequently, the originally present microbial amount could also be similar in all cases. When soils with high amount of biochar addition were investigated, the sudden decrease in $\mathrm{N}_{2}$ fixation rates, especially in the case of arable soils, indicates potential negative effects of excess biochar application on $\mathrm{N}_{2}$-fixing microbial activities.

In general, our results showed that in natural environmental conditions, acetylene reduction and consequently $\mathrm{N}_{2}$ fixation rates vary significantly among different land use types and cultivation systems. These rates might be influenced by biochar application where microbial activities in non-legumeplanted soils can be suppressed to the point that biological $\mathrm{N}_{2}$ fixation might be reduced to a nominal level. These findings confirm the necessity for long-term studies investigating the effects of soil alterations on soil nutrient dynamics and nitrogen cycling processes.

\section{Conclusions}

Agriculturally more active areas such as tilled arable lands or vineyards can receive annual soil enhancers such as fertilizer or biochar additions, which can cause a disruption in its biochemical processes. Our study highlights that soil biological and chemical differences can be developed over time between land use types due to human interferences such as tillage, fertilizer addition, and crop rotation, as we found in the case of total $\mathrm{N}$ and SOC contents with higher values in the case of forest and grassland compared to arable or vineyard soils. Seasonal changes in environmental conditions can influence soil chemical changes, especially differences in nutrient concentrations in spring samples within land use types (e.g., $\mathrm{NO}_{3}{ }^{-} \mathrm{N}$ for all land uses or $\mathrm{NH}_{4}{ }^{+}-\mathrm{N}$ in the case of forest and 
531 grassland). Among land uses, we found that total N and SOC

532 values can increase considerably during winter and spring for

533 forest and grassland soils, mostly as a result of litter decom-

534 position. In agreement with soil chemical changes, we also

535 observed the influence of human impact on soil microbial

536 communities, especially on ARA potentials. We found that

537 the more interference occurred at a given land use site, the

538 higher the potential BNF rates were (arable $>$ vineyard $>$

539 grassland $>$ forest soils). The present study demonstrates that

540 the smaller amount of biochar addition can increase, while the

541 higher biochar amendments can inhibit BNF rates. However,

542 the type of the biochar is also an important factor in the ARA

543 rates, as we found the most positive impacts in biochar amend-

544 ments prepared at the lowest pyrolysis temperature. Overall,

545 our study emphasizes that careful planning and analyses

546 should be implemented prior to soil enhancer additions to 547 lands.

Funding information This material is based upon work supported by the Hungarian National Research Fund (OTKA/NKFI) project OTKA PD116157. This paper was also supported by the János Bolyai Research Scholarship of the Hungarian Academy of Sciences.

\section{References}

Atkinson CJ, Fitzgerald JD, Hipps NA (2010) Potential mechanisms for achieving agricultural benefits from biochar application to temperate soils: a review. Plant Soil 337:1-18. https://doi.org/10.1007/s11104$010-0464-5$

Belnap J (2003) The world at your feet: desert biological soil crusts. Front Ecol Environ 1:181-189. https://doi.org/10.1890/15409295(2003)001[0181:TWAYFD]2.0.CO;2

Bezdicek DF, Kennedy AC (1998) Microorganisms in action. Blackwell Scientific Publications, Oxford

Blackmer AM, Bremner JM (1978) Inhibitory effect of nitrate on reduction of $\mathrm{N}_{2} \mathrm{O}$ to $\mathrm{N}_{2}$ by soil microorganisms. Soil Biol Biochem 10: 187-191. https://doi.org/10.1016/0038-0717(78)90095-0

Cusack DF, Silver W, McDowell WH (2009) Biological nitrogen fixation in two tropical forests: ecosystem-level patterns and effects of nitrogen fertilization. Ecosystems 12:1299-1315. https://doi.org/10. 1007/s10021-009-9290-0

DeLuca TH, MacKenzie MD, Gundale MJ (2009) Biochar effects on soil nutrient transformations. In: Lehmann J, Joseph S (eds) Biochar for environmental management: science and technology. Earthscan, London, pp 251-270

Fageria VD (2001) Nutrient interactions in crop plants. J Plant Nutr 24: 1269-1290. https://doi.org/10.1081/PLN-100106981

Gaskin JW, Speir RA, Harris K, Das KC, Lee RD, Morris LA, Fisher DS (2010) Effect of peanut hull and pine chip biochar on soil nutrients, corn nutrient status, and yield. Agron J 102:623-633. https://doi.org/ 10.2134/agronj2009.0083

Halbleib CM, Ludden PW (2000) Regulation of biological nitrogen fixation. J Nutr 130:1081-1084

Horel A, Bernard R, Mortazavi B (2014) Impact of crude oil exposure on nitrogen cycling in a previously impacted Juncus roemerianus salt marsh in the northern Gulf of Mexico. Environ Sci Pollut Res 21: 6982-6993. https://doi.org/10.1007/s11356-014-2599-z

Horel Á, Tóth E, Gelybó G, Dencső M, Potyó I (2018) Soil $\mathrm{CO}_{2}$ and $\mathrm{N}_{2} \mathrm{O}$ emission drivers in a vineyard (Vitis vinifera) under different soil management systems and amendments. Sustainability 10:1811. https://doi.org/10.3390/su10061811

Kanwar RS, Baker JL, Baker DG (1988) Tillage and split N-fertilization effects on subsurface drainage water quality and crop yields. Transactions of the ASAE 31:0453-0461. https://doi.org/10. $13031 / 2013.30730$

Limmer C, Drake HL (1996) Non-symbiotic $\mathrm{N}_{2}$-fixation in acidic and $\mathrm{pH}$-neutral forest soils: aerobic and anaerobic differentials. Soil Biol Biochem 28:177-183. https://doi.org/10.1016/0038-0717(95) 00118-2

Maharning AR, Mills AAS, Adl SM (2009) Soil community changes during secondary succession to naturalized grasslands. Appl Soil Ecol 41:137-147. https://doi.org/10.1016/j.apsoil.2008.11.003

Masson-Boivin C, Giraud E, Perret X, Batut J (2009) Establishing nitrogen-fixing symbiosis with legumes: how many rhizobium recipes? Trends Microbiol 17:458-466. https://doi.org/10.1016/j.tim. 2009.07.004

Mia S, van Groenigen JW, van de Voorde TFJ, Orama NJ, Bezemer TM, Mommer L, Jeffery S (2014) Biochar application rate affects biological nitrogen fixation in red clover conditional on potassium availability. Agric Ecosyst Environ 191:83-91. https://doi.org/10. 1016/j.agee.2014.03.011

Mijangos I, Pérez R, Albizu I, Garbisu C (2006) Effects of fertilization and tillage on soil biological parameters. Enzym Microb Technol 40: 100-106. https://doi.org/10.1016/j.enzmictec.2005.10.043

Mulongoy K (1995) Technical paper 2: biological nitrogen fixation. In: Tripathl BR, Psychas PJ (eds) Source book for alley farming research

Ouyang L, Wang F, Tang J, Yu L, Zhang R (2013) Effects of biochar amendment on soil aggregates and hydraulic properties. J Soil Sci Plant Nutr 13:991-1002

Quilliam RS, DeLuca TH, Jones DL (2013) Biochar application reduces nodulation but increases nitrogenase activity in clover. Plant Soil 366:83-92. https://doi.org/10.1007/s11104-012-1411-4

Reddy KR, Patrick WH, Broadbent FE (1984) Nitrogen transformations and loss in flooded soils and sediments. CRC Crit Rev Environ Control 13:273-309. https://doi.org/10.1080/10643388409381709

Rillig MC, Wagner M, Salem M, Antunes PM, George C, Ramke H-G, Titirici M-M, Antonietti M (2010) Material derived from hydrothermal carbonization: effects on plant growth and arbuscular mycorrhiza. Appl Soil Ecol 45:238-242. https://doi.org/10.1016/j.apsoil. 2010.04.011

Rondon MA, Lehmann J, Ramírez J, Hurtado M (2007) Biological nitrogen fixation by common beans (Phaseolus vulgaris L.) increases with bio-char additions. Biol Fertil Soils 43:699-708. https://doi. org/10.1007/s00374-006-0152-z

Roper MM, Smith NA (1991) Straw decomposition and nitrogenase activity $\left(\mathrm{C}_{2} \mathrm{H}_{2}\right.$ reduction) by free-living microorganisms from soil: effects of $\mathrm{pH}$ and clay content. Soil Biol Biochem 23:275-283. https://doi.org/10.1016/0038-0717(91)90064-Q

Santi C, Bogusz D, Franche C (2013) Biological nitrogen fixation in nonlegume plants. Ann Bot 111:743-767. https://doi.org/10.1093/aob/ mct048

Schiewer S, Horel A (2017) Biodiesel addition influences biodegradation rates of fresh and artificially weathered diesel fuel in Alaskan sand. J Cold Reg Eng 31:04017012. https://doi.org/10.1061/(ASCE)CR. 1943-5495.0000138

Steiner C, Teixeira WG, Lehmann J, Nehls T, de Macêdo JLV, Blum WEH, Zech W (2007) Long term effects of manure, charcoal and mineral fertilization on crop production and fertility on a highly weathered Central Amazonian upland soil. Plant Soil 291:275290. https://doi.org/10.1007/s11104-007-9193-9

Surda P, Lichner L, Nagy V, Kollar J, Iovino M, Horel A (2015) Effects of vegetation at different succession stages on soil properties and water flow in sandy soil. Biologia 70:1474-1479. https://doi.org/10.1515/ biolog-2015-0172
587

588

589

590

591

592

593

594

595

596

597

598

599

600

601

602

603

604

605

606

607

608

609

610

611

612

613

614Q3

615

616

617

618

619

620

621

622

623

624

625

626

627

628

629

630

631

632

633

634

635

636

637

638

639

640

641

642

643

644

645

646

647

648

649

650

651 652 
653

654

655

656

657

658

659

660

661

662

663

664

675
Thies JE, Rillig M (2009) Characteristics of biochar: biological properties. In: Lehmann J, Joseph S (eds) Biochar for environmental management: science and technology. Earthscan, London, pp 85-105

Uzoma KC, Inoue M, Andry H, Fujimaki H, Zahoor A, Nishihara E (2011) Effect of cow manure biochar on maize productivity under sandy soil condition. Soil Use Manag 27:205-212. https://doi.org/ 10.1111/j.1475-2743.2011.00340.x

Vitousek PM, Aber JD, Howarth RW, Likens GE, Matson PA, Schindler DW, Schlesinger WH, Tilman DG (1997) Human alteration of the global nitrogen cycle: sources and consequences. Ecol Appl 7:737750. https://doi.org/10.1890/1051-0761(1997)007[0737: HAOTGN]2.0.CO;2
Welsh DT, Bourgués S, de Wit R, Herbert RA (1996) Seasonal variations in nitrogen-fixation (acetylene reduction) and sulphate-reduction rates in the rhizosphere of Zostera noltii: nitrogen fixation by sulphate-reducing bacteria. Mar Biol 125:619-628. https://doi.org/ 10.1007/BF00349243

Ye R, Wright AL, Inglett K, Wang Y, Ogram AV, Reddy KR (2009) Landuse effects on soil nutrient cycling and microbial community dynamics in the Everglades agricultural area, Florida. Commun Soil Sci Plant Anal 40:2725-2742. https://doi.org/10.1080/ 00103620903173772
665

666

667

668

669

670

671

672

673

674 